\title{
Microfacies and Depositional Environment of Mishrif Formation, North Rumaila Oilfield, Southren Iraq
}

\author{
Muslim M. Al-Ali ${ }^{*}$, Maher M. Mahdi², Rasha A. Alali \\ ${ }^{1}$ Basrah Oil Company, Ministry of Oil, Basrah, Iraq \\ ${ }^{2}$ Geology Department, College of Science, University of Basrah
}

*Corresponding Author: Muslim M. Al-Ali, Basrah Oil Company, Ministry of Oil, Basrah, Iraq

\begin{abstract}
Mishrif Formation is one the main oil reservoirs in southern Iraq. This study analyze the microfacies and depositional environment for Mishrif Formation in North Rumaila oilfield. The study was based on the analysis of 17 wells core. The Mishrif Formation represents deposition in a carbonate platform ramp system, with scattered patch reefs and shoals developed across the ramp margin and the platform top. It is characterize by skeletal grains (bioclasts) which are dominated such as Foraminifera, Rudist, Calcareous Algae and other skeletal grains included molluscs shell fragments with Chondrodonta sometimes, and Echinoderms while non-skeletal grains are less abundant which are represented by Peloids and Ooids. The sedimentological and stratigraphic analysis of Mishrif Formation core led to identification of 16 facies association, 7 of which are found in the $m B$ unit (lower part of the Formation) whereas they are deposited in outer ramp, mid ramp, ramp margin and lagoon, while 9 in the mA unit (upper part of the formation) which are deposited in intra plate basin, mid ramp, inner ramp, ramp margin and lagoonal supra tidal.

According to the petrography analysis of Mishrif Formation, the foraminifera fossils is dominated in the formation, by the study there are 4 foraminiferal group / microfacies association (Oligosteginid/planktonic foraminiferal, Alveolinid association, Dicyclina/high diversity foraminiferal and Miliolid / low diversity foraminiferal) can be identified and build the sedimentary model with microfacies which are applicable to the Mishrif Formation.
\end{abstract}

Keywords: Mishrif Formation, Rumaila oilfield, Microfacies, Sedimentary model.

\section{INTRODUCTION}

Mishrif Formation is the most significant carbonate reservoir unit in Iraq, it includes up to $30 \%$ of total Iraqi oil reserves (Aqrawi et al., 2010). The formation is composed of thick carbonates of middle Cenomanian - early Turonian age (Chatton and Hart, 1961), that deposited on a basin-wide shallow water platform, accommodation space was supplied by a major eustatic seal-level rise in the middle Cenomanian (Haq et al., 1987; Gale et al., 2008). The Mishrif and underlying Rumaila formations were originally described in southern Iraq in well Zb-3 in Zubair oilfield (Aqrawi et al., 2010). The contact between the Mishrif and Rumaila Formations is gradational, the Mishrif Formation is unconformably overlain by the Khasib Formation (Aqrawi 1995). The microfacies of Mishrif Formation were classified based on Folk's (1962) and Dunham's (1962), adjusted by Embry and Klovan (1972) and revised by Wright (1992), this classification is depending on the mud- or grainsupported textural types.

\subsection{Study Area}

North Rumaila oilfield is a giant oil field located in southern Iraq which is approximately $32 \mathrm{Km}$ from Kuwait border and about 50 kilometer west of Basra city, between coordinate $47^{\circ} 16^{\prime} 46^{\prime \prime}$ $47^{\circ} 26^{\prime} 14^{\prime \prime}$ Easting and $38^{\circ} 28^{\prime} 34^{\prime \prime}-38^{\circ} 42^{\prime} 30.8^{\prime \prime}$ Northing. The longitudinal axis of the North Rumaila oilfield is $30 \mathrm{~km}$, while the width is $20 \mathrm{~km}$. It is covered an area about $600 \mathrm{~km}^{2}$. Zubair, Tuba oilfields located at the east, while West Qurna oilfield located at the north and Ratawi oil field in the west of North Rumaila oilfield, it is consists of subsurface anticlines which are trending N-S (Karim, 1992), it is separated by saddle form south Rumaila oilfield subsurface anticlines (Fig. 1). 


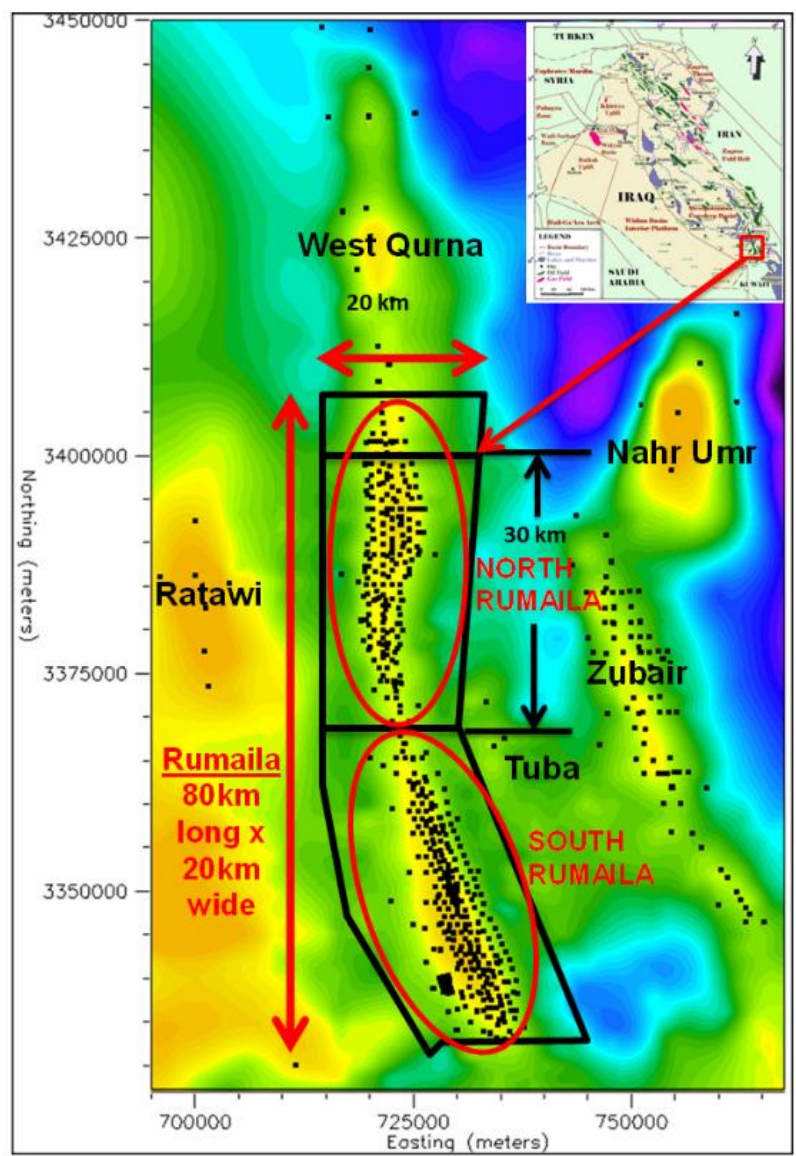

Fig1. Location map showing to the Rumaila oil field

\section{METHODOLOGY}

Methodology in this study includes the following:

1. Collection data: 22 core sample were cut, these core sample distribute on 17 wells in the study area, the wells have been selected according to location of each well in the North Rumaila oil field and availability of core interval covering almost all units of Mishrif Formation.

2. Core description with correction to the depth for core sample interval with wireline log depth.

3. 208 conventional thin-sections have been for studied the petrography and microfacies of Mishrif Formation on the 17 wells along the North Rumaila oilfield.

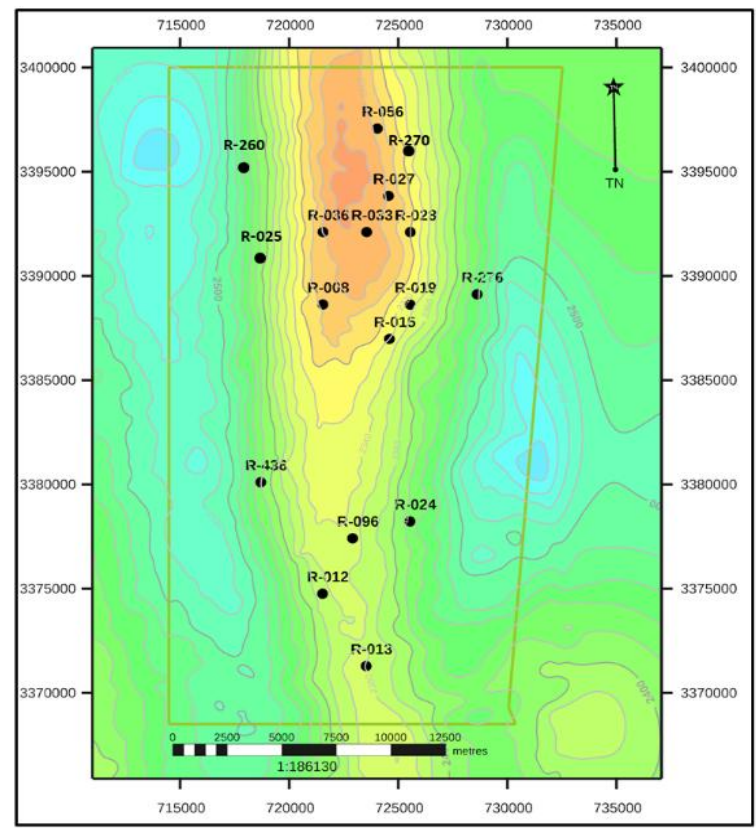

Fig2. Distribution of core wells in the study area (North Rumaila oilfield) 


\section{MICROFACIES}

The sedimentological and stratigraphic analysis of the Mishrif core led to the identification of 16 microfacies, 7 occur in the $\mathrm{mB}$ (lower part of the formation) and 9 in the $\mathrm{mA}$ (upper part of the formation).

\subsection{Microfacies in the Mb Interval}

\subsubsection{Benthonic Foraminiferal Lime-Wackestone Microfacies}

This microfacies including miliolids and alveolinids, common gastropod fragments, with peloids, this biofacies are readily identifiable due to the abundant preferential dolomitization of burrows/cavity fills, abundant burrowed hard grounds, karstic features affecting the tight and muddy sediments, It is present in the most of the study area, locally creating thick continuous successions in wells R-033, R056, R-036, R-025 and R-436. The standard of microfacies (SMF) of this facies is 16, 17 which lie within facies zone (FZ) 8 (Flugel, 1986) Fig. 3.

\subsubsection{Prealveolinids and Dicyclinid Lime-Wackestone to Packstone Microfacies}

This microfacies is defined by the presence of large prealveolinids and dicyclinids, also it has a large rudist fragments. Bioturbation was noticed in this microfacies. Textures are more heterogeneous and porous than Wackestone benthic foraminifera biofacies. This association is variably present in the study area wells, while in R-027, R-033 and R-436 it is poorly developed. The standard of microfacies (SMF) of this facies is 9, 11 which lie within facies zone (FZ) 6, 7 (Flugel, 1986) Fig.3.

\subsubsection{Benthonic Foraminiferal Lime-Packstones to Grainstone Microfacies}

This microfacies is characterized by fine to relatively coarse-grained packstones to grainstones dominated by fine echinoderm debris and benthonic foraminifera (miliolids and textulariids). The observed facies are very similar to those occurring in mixed rudist/bivalve/echinoderm lime-packstone to lime grainstone biofacies, and can be differentiated mainly based on slight compositional differences (mainly through microscopic analysis). In core, this biofacies appears to be relatively less sorted and with slightly more heterogeneous textures than mixed rudist/bivalve/echinoderm limepackstone to lime-grainstone biofacies. This group are present in R-027, R-036, R-056 and R-025. The standard of microfacies (SMF) of this facies is 11, 12 which lie within facies zone (FZ) 6 (Flugel, 1986) Fig.4.

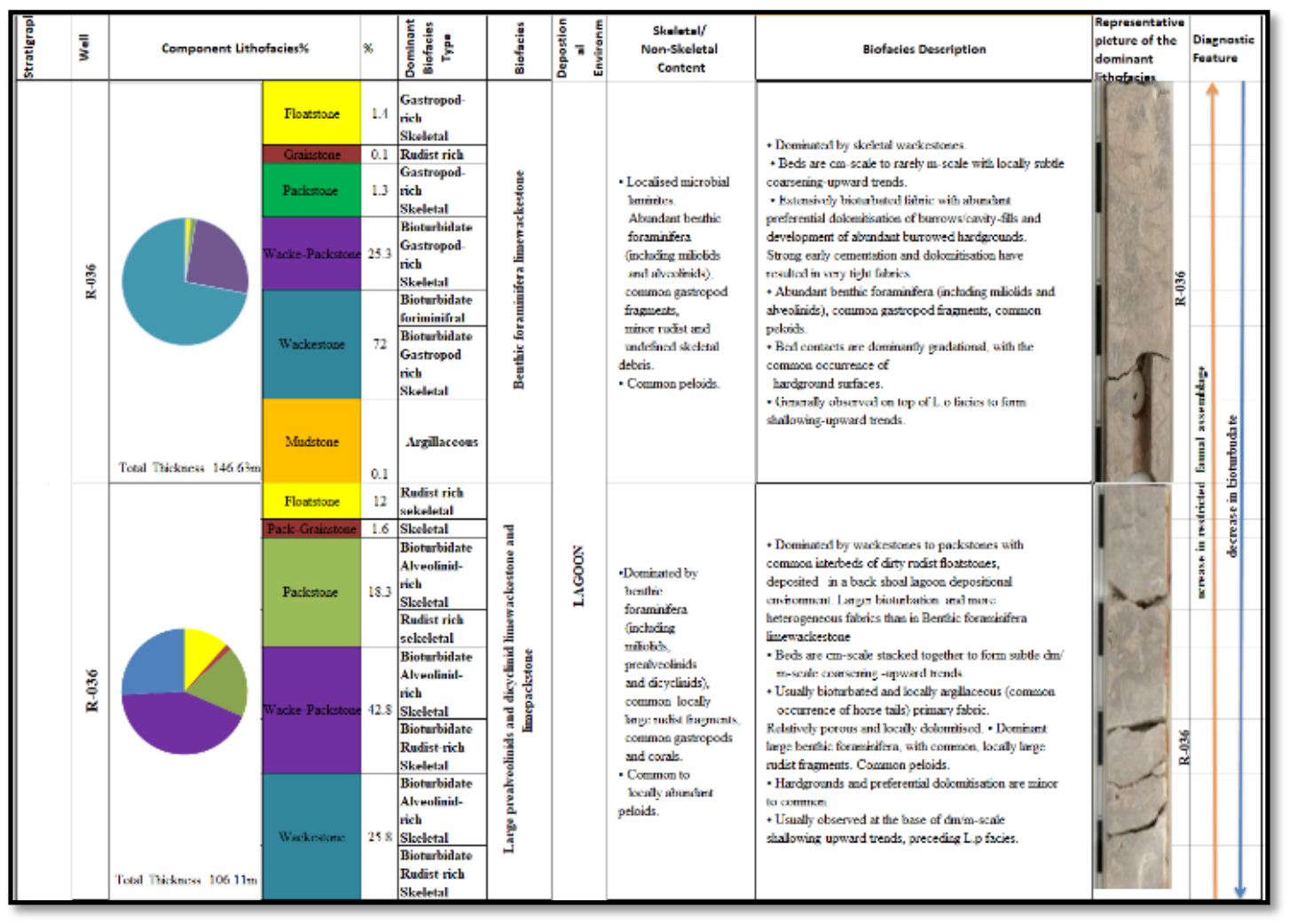

Fig3. Distribution of microfacies on $m B$ unit of Mishrif Formation with core description to the same interval. 


\subsubsection{Fossiliferous Lime-Packstones to Grainstone Microfacies}

Comparatively fine to medium grained packstones to grainstones comprising abundant bivalve (rudist) and echinoderm debris, with following to benthic foraminifera. In thin-section increased bivalve content of these biofacies relative to Echinoderm and benthic foraminifera lime-packstones to grainstone microfacies clearly visible. Slightly more argillaceous layers and rudist fragments present in these biofacies. small echinoderm fragments are recorded. It is present in R-033, R-036, R-027, R-019 and R-056. The standard of microfacies (SMF) of this facies is 12, 13 which lie within facies zone (FZ) 5, 6 (Flugel, 1986) Fig.4.

\subsubsection{Rudist Lime-Packstone to Rudstone Microfacies}

This biofacies is defined by the abundant of large rudist content within strongly filtered packstone to rudstone textures, with subordinate muddier wackestone to floatstone textures. Fabrics are usually massive and merged with no visible bed-scale trends and rare possible lamination. This biofacies association is commonly observed throughout the study area. The standard of microfacies (SMF) of this facies is 7, 12 which lie within facies zone (FZ) 5 (Flugel, 1986) Fig.5.

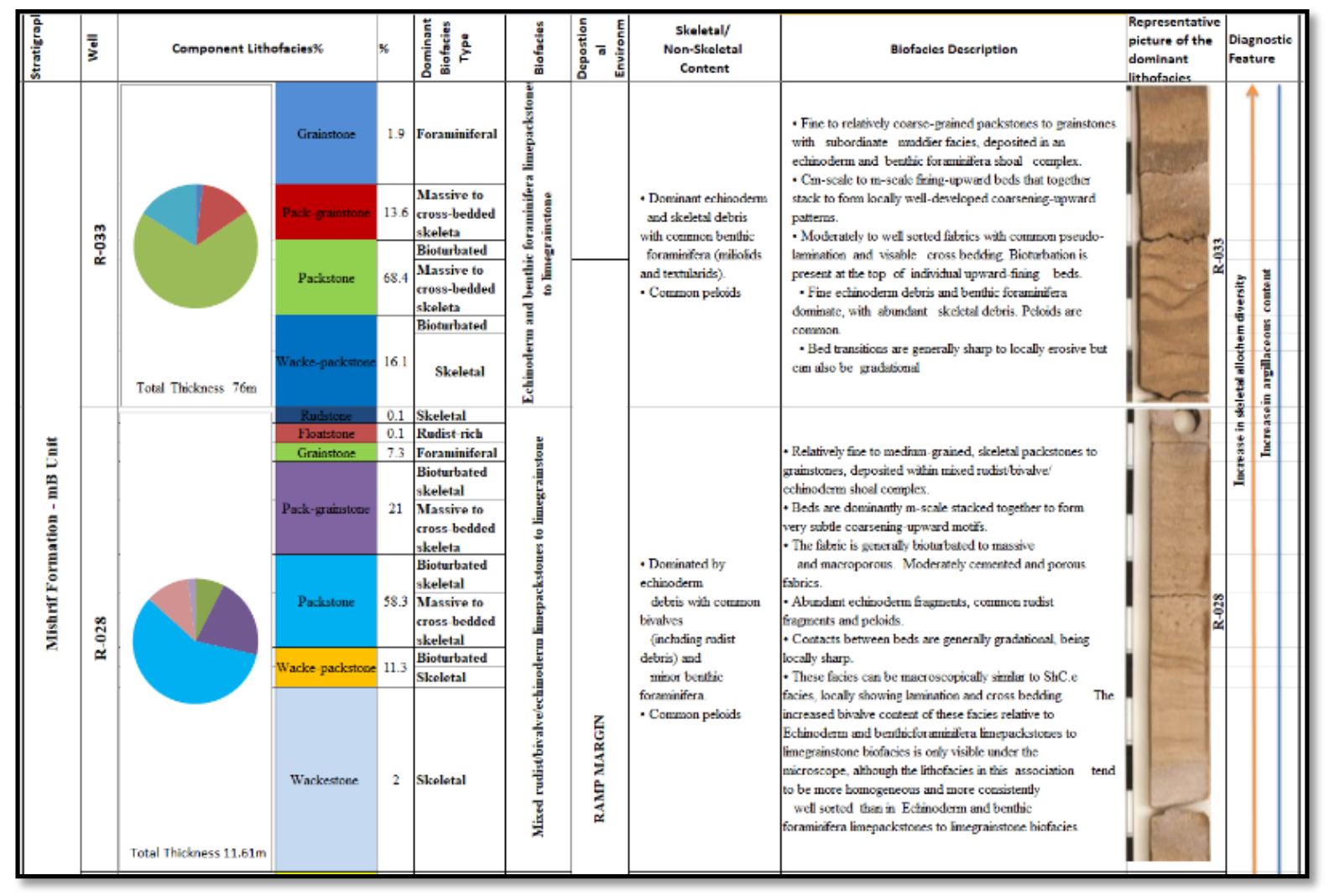

Fig4. Distribution of benthonic foraminiferal lime-packstones to grainstone microfacies with fossiliferous limepackstones to grainstone microfacies in $\mathrm{mB}$ unit.

\subsubsection{Benthonic and Planktonic Foraminiferal Lime-Wackestone to Lime-Packstone Microfacies}

The muddy texture of this biofacies are characterized by strong bioturbation and fine seams resulting in common pseudo-nodular texture. Grey to black chert nodules are common and the skeletal content is represented by minor undifferentiated skeletal fragments, benthic and planktonic foraminifera only visible in thin section. Moderate cementation and poor to moderate micropore-dominated pore systems. This biofacies are observed in wells R-012, R-013, R-024 and R-028. The standard of microfacies (SMF) of this facies is 5, 6 which lie within facies zone (FZ) 4 (Flugel, 1986) Fig.5.

\subsubsection{Oligosteginids Lime-Mudstone to Wackestone Microfacies}

Argillaceous, laminated and bioturbated mudstones to wackestones with black chert nodules. Very fine-grained skeletal allochems from planktonic foraminifera and oligosteginids were diagonsed. This biofacies observed at the base of $\mathrm{mB}$ unit in well R-036, R-096 and R-024. The standard of microfacies (SMF) of this facies is 2, 3 which lie within facies zone (FZ) 2, 3 (Flugel, 1986) Fig.5. 


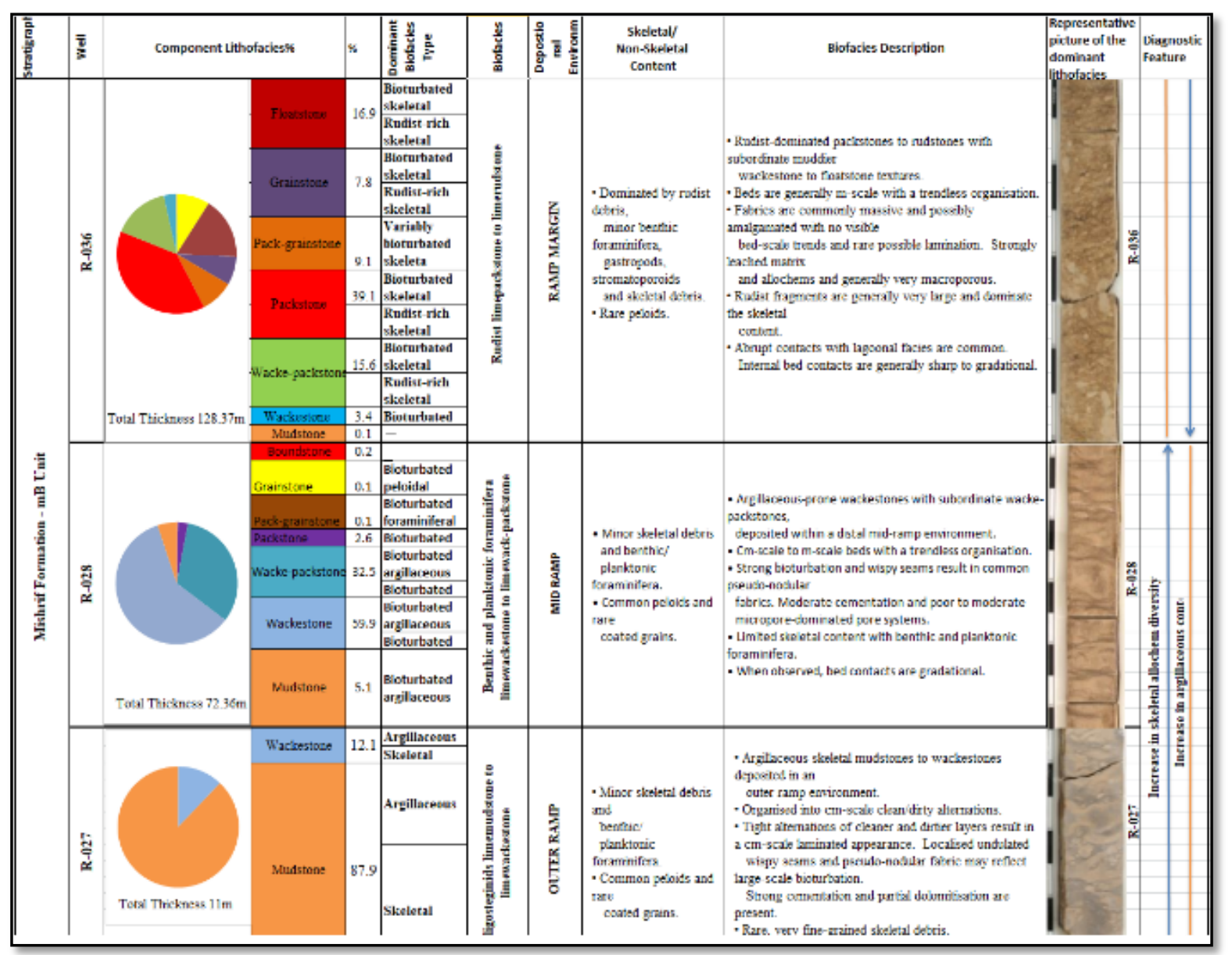

Fig5. Distribution of rudist lime-packstone to rudstone microfacies, benthonic and planktonic foraminiferal limewackestone to packstone microfacies with oligosteginids lime-mudstone to lime-wackestone microfacies in $\mathrm{mB}$ unit

\subsection{Microfacies in The Ma Interval}

\subsubsection{Benthonic Foraminifera Lime-Wackestones to Packstones Microfacies}

This biofacies is defined by the abundant benthic foraminifera, algal crusts and gastropods. The beds are arranged in subtle coarsening-upward trends. Mainly represented by intraclast-rich wackestones to packstones, showing highly variable fabrics, from microbial laminates to pisolitic and brecciated fabrics. Abundant cracks and green clay in fills. Common stylolitised contacts, erosive surfaces and hardgrounds characterize these biofacies. These biofacies present in the lower part of the study area ( R-012, R-013, R-436). The standard of microfacies (SMF) of this facies is 20,23 which lie within facies zone (FZ) 9 (Flugel, 1986) Fig.6.

\subsubsection{Dicyclinids Lime-Wackestones to Packstones Microfacies}

This microfacies is dominated by bioturbated wackestones to packstones with abundant benthonic foraminifera and gastropods. It is characterised by the presence of abundant large benthonic foraminifera especially dicyclinids with gastropod fragments and by the absence of large rudist fragments. This biofacies is only observed in the northern part of the study area (R-019, R-027, R-033, and R-036). The standard of microfacies (SMF) of this facies is 18,19 which lie within facies zone (FZ) 8 (Flugel, 1986) Fig.6.

\subsubsection{Peloidal Lime-Packstone to Grainstones Microfacies}

Coated grain, aggregate grain and peloid-dominated packstone to grainstones with rare wackepackstones forming thin beds only occurring in wells R-028 and R-036. Benthic foraminifera are generally observed at the nuclei of coated grains.

The standard of microfacies (SMF) of this facies is 11, 16 which lie within facies zone (FZ) 6,7 (Flugel, 1986) Fig.6. 


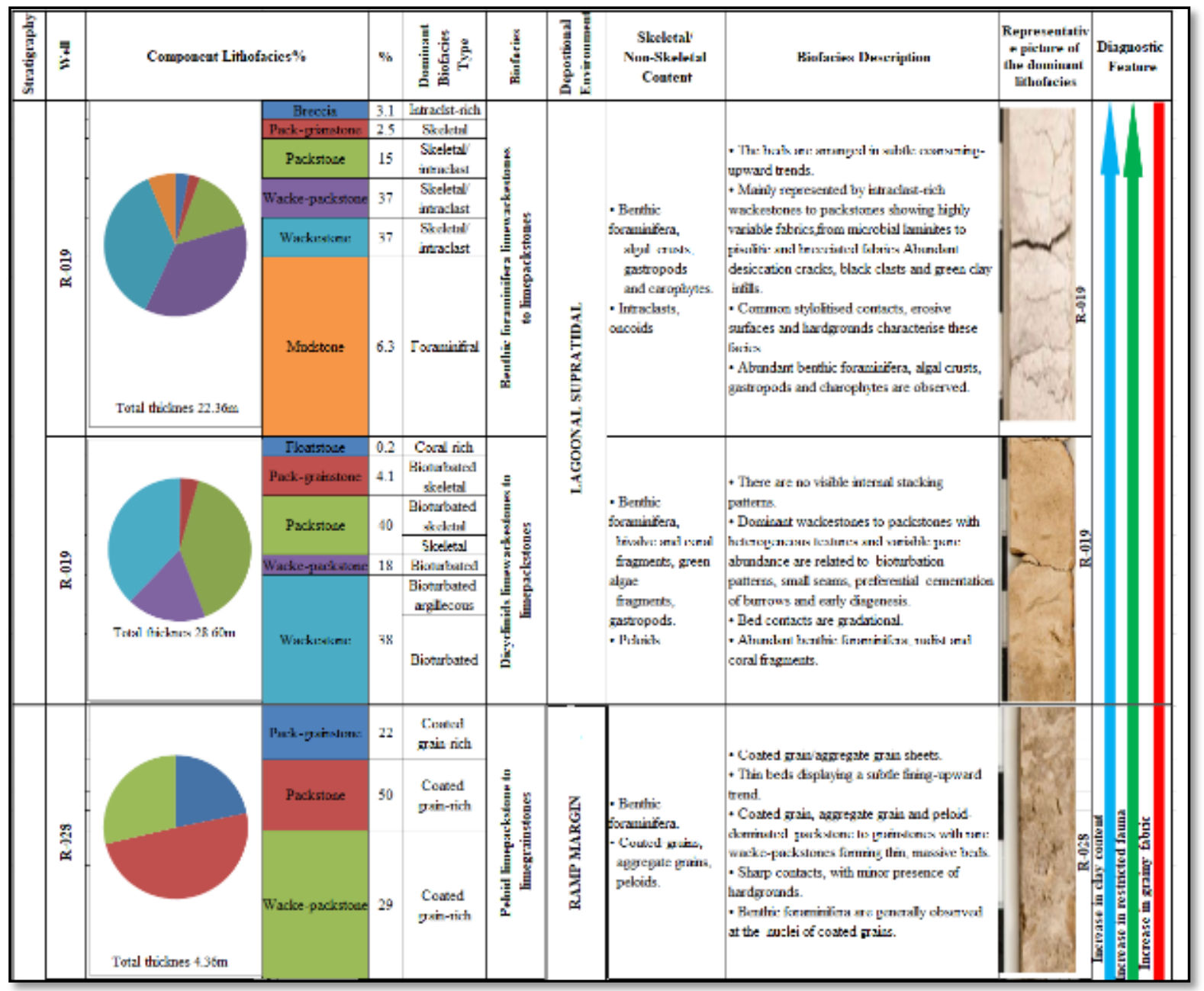

Fig6. Distribution of benthonic foraminifera lime-wackestones to packstones microfacies, dicyclinids limewackestones to packstones microfacies with peloidal lime-packstone to grainstones microfacies in mA unit.

\subsubsection{Rudist-Coral Lime-Wackestone to Packstone Microfacies}

Variably rudist and/or coral are dominated in this microfacies, wacke-packstones and sometimes floatstones with subordinate gastropods, benthic foraminifera and other reef-building ecology are classified to this microfacies. This biofacies in the mA zone Mishrif Formation, generally show more disorganized and preferentially cemented and fractured textures, with massive beds stacked in no clear stratigraphic trends. This biofacies occurs in wells R-027, R-028 and R-036, with possible very thin intervals in R-019. The standard of microfacies (SMF) of this facies is 7 which lie within facies zone (FZ) 5 (Flugel, 1986) Fig.7.

\subsubsection{Large Benthonic Foraminiferal Lime-Wacke to Packstones Microfacies}

Strongly bioturbated wacke to packstones with subordinate wackestones usually characterized by a clay/organic-rich bioturbated mudstone at the base, which contains a hardground. This biofacies present a more intense large-scale bioturbation and dominant large benthic foraminifera (dicyclinids) that are not observed in the $\mathrm{mB}$ unit. This biofacies present throughout the study area except R-019. The standard of microfacies (SMF) of this facies is 4, 7 which lie within facies zone (FZ) 4,5 (Flugel, 1986) Fig.7.

\subsubsection{Benthonic Lime-Packstones to Grainstones Microfacies}

Packstones to grainstones typically dominated by peloids, aggregate and coated grains, with rare planktonic foraminifera. These facies occur in R-012, R-436. Locally rudist-rich wacke-packstone to floatstone with common benthic foraminifera (miliolids) and no planktonic foraminifera. This particular biofacies is only observed in R-027. The standard of microfacies (SMF) of this facies is 4,6 which lie within facies zone (FZ) 4 (Flugel, 1986) Fig.8. 


\subsubsection{Planktonic Lime-Wackestones Microfacies}

Strongly bioturbated wackestones with a pseudo-nodular texture are associated to the large, relatively clean burrows, and the common thin seams surrounding them. Black chert nodules are locally present and a hardground surface is observed in the lowermost part of the succession. These facies are similar to large benthonic foraminiferal lime-wacke to lime-packstones biofacies, but can be distinguished due to the largely limited skeletal content (mainly planktonic foraminifera).This biofacies observed in R025 and R-033 where texture are slightly grainier. The standard of microfacies (SMF) of this facies is 4,3 which lie within facies zone (FZ) 3 (Flugel, 1986), Fig.8.

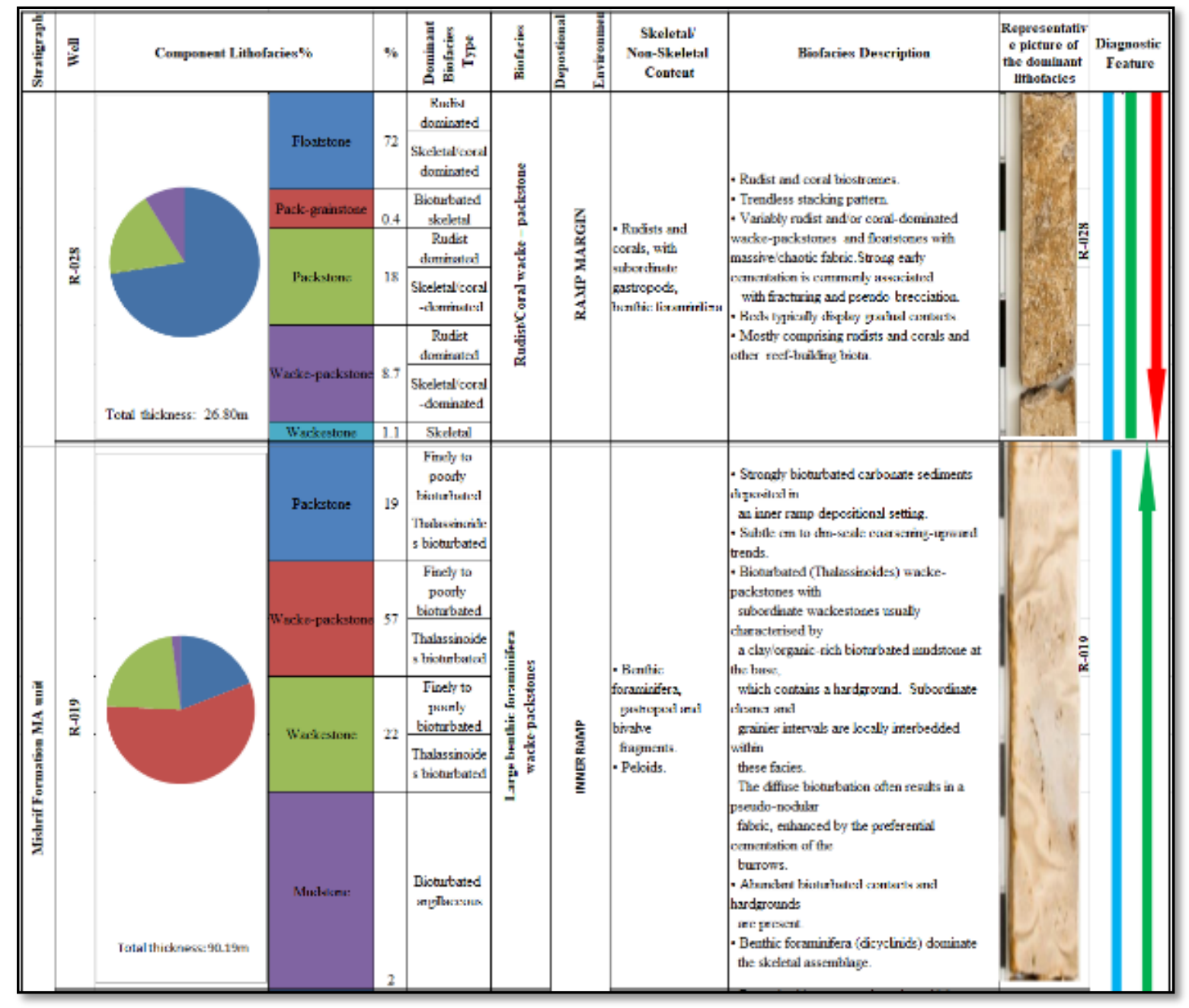

Fig7. Distribution of rudist-coral lime-wackestone to lime-packstone microfacies with large benthonic foraminiferal lime-wacke to lime-packstones microfacies in $\mathrm{mA}$ unit.

\subsubsection{Ostracod Limewackestones with Mudstones Microfacies}

This microfacies characterized by thin-layered and small laminated, $\mathrm{mm}$ to $\mathrm{cm}$-scale bioturbated wackestones with subordinate mudstone textures and common argillaceous content. Beds are cm-scale and are arranged in lighter/darker colour alternations, reflecting variable clay content and microporosity distribution. Ostracod has been observed. This biofacies is occurs in well R-033 and R025. The standard of microfacies (SMF) of this facies is 3 which lie within facies zone (FZ) 3 (Flugel, 1986), Fig.8.

\subsubsection{Planktonic Lime-Mudstones Microfacies}

This microfacies recognize by thin-layered to locally small laminated, bioturbated mudstones with variable abundance of organic matter. Organic-rich intervals comprise black, shaly mudrocks with no visible skeletal content, resulting in a very distinct appearance. More carbonate-rich layers are thicker and lighter in color, with common planktonic foraminifera, rare to minor ostracod fragments and local bioturbation. The standard of microfacies (SMF) of this facies is 1 which lie within facies zone (FZ) 2, 1 (Flugel, 1986) Fig.8. 


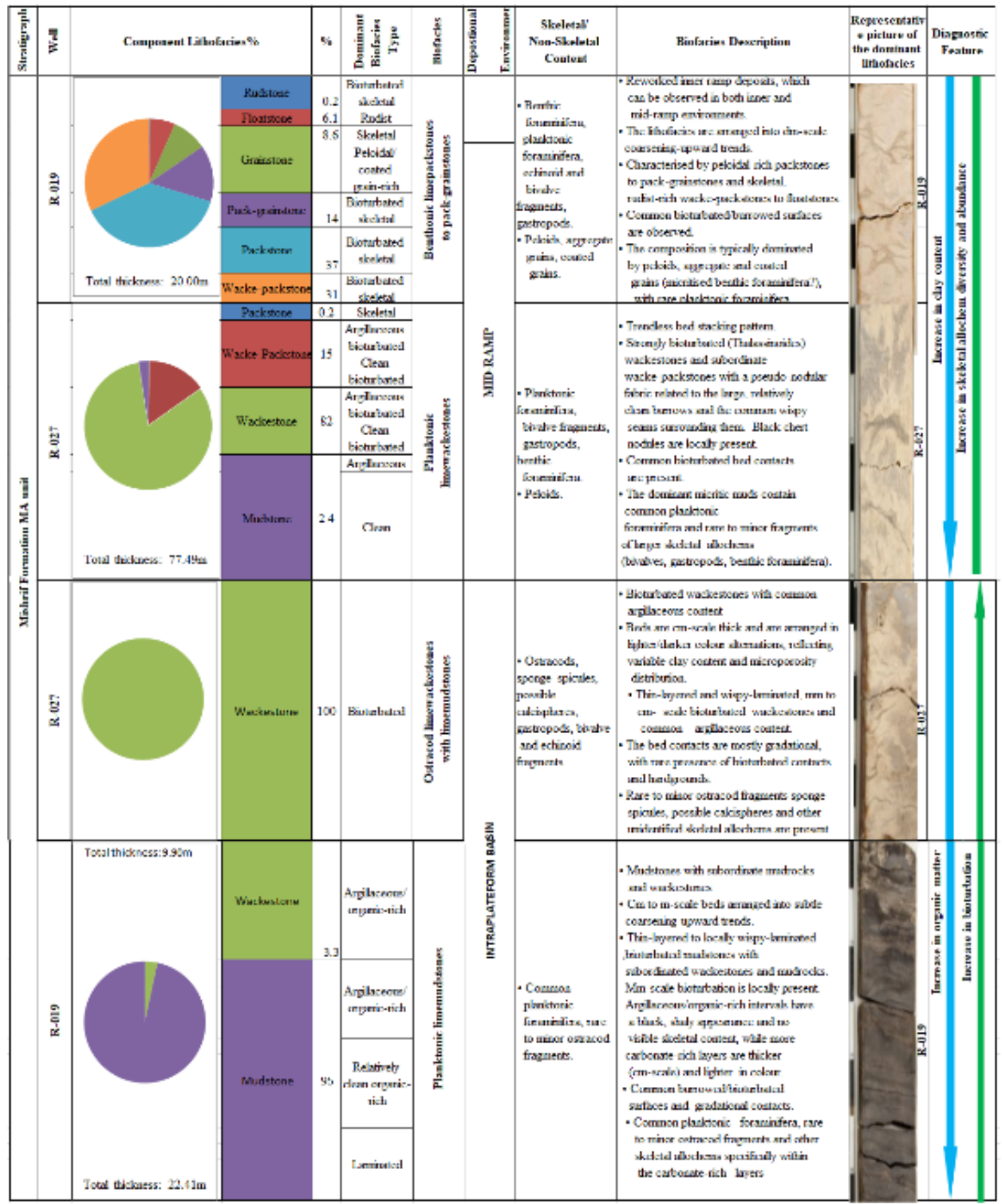

Fig8. Distribution of benthonic lime-packstones to lime-grainstones microfacies, benthonic lime-packstones to lime-grainstones microfacies, ostracod limewackestones with limemudstones microfacies and planktonic limemudstones microfacies in $\mathrm{mA}$ unit.

\section{SEDimentary ENVIRONMENT}

The depositional model of Mishrif Formation was built from the results of the microfacies analysis applying Flugel's chart for the biofacies, the formation is characterize by four types of biofacies, where each type of them indicator to depositional environment as follow:

a. Oligosteginid/planktonic foraminiferal association: forming fine-grained (micritic) wackestones/packstones identified in outer platform/shelf, open marine environment

b. Alveolinid association: forming coarse, foraminiferal/bioclastic packstones - wackestones, sometimes associated with reefal debris identified in peri-reefal, unrestricted marine environment

c. Dicyclina/high diversity foraminiferal association: forming coarse, foraminiferal/bioclastic packstones/grainstones, sometimes associated with dasycladacean/algal debris identified in unrestricted lagoon - back-reef/shoal environment 
d. Miliolid/low diversity foraminiferal association: forming medium-fine, foraminiferal/bioclastic packstones - wackestones, sometimes associated with dasycladacean debris identified in restricted lagoon environment.

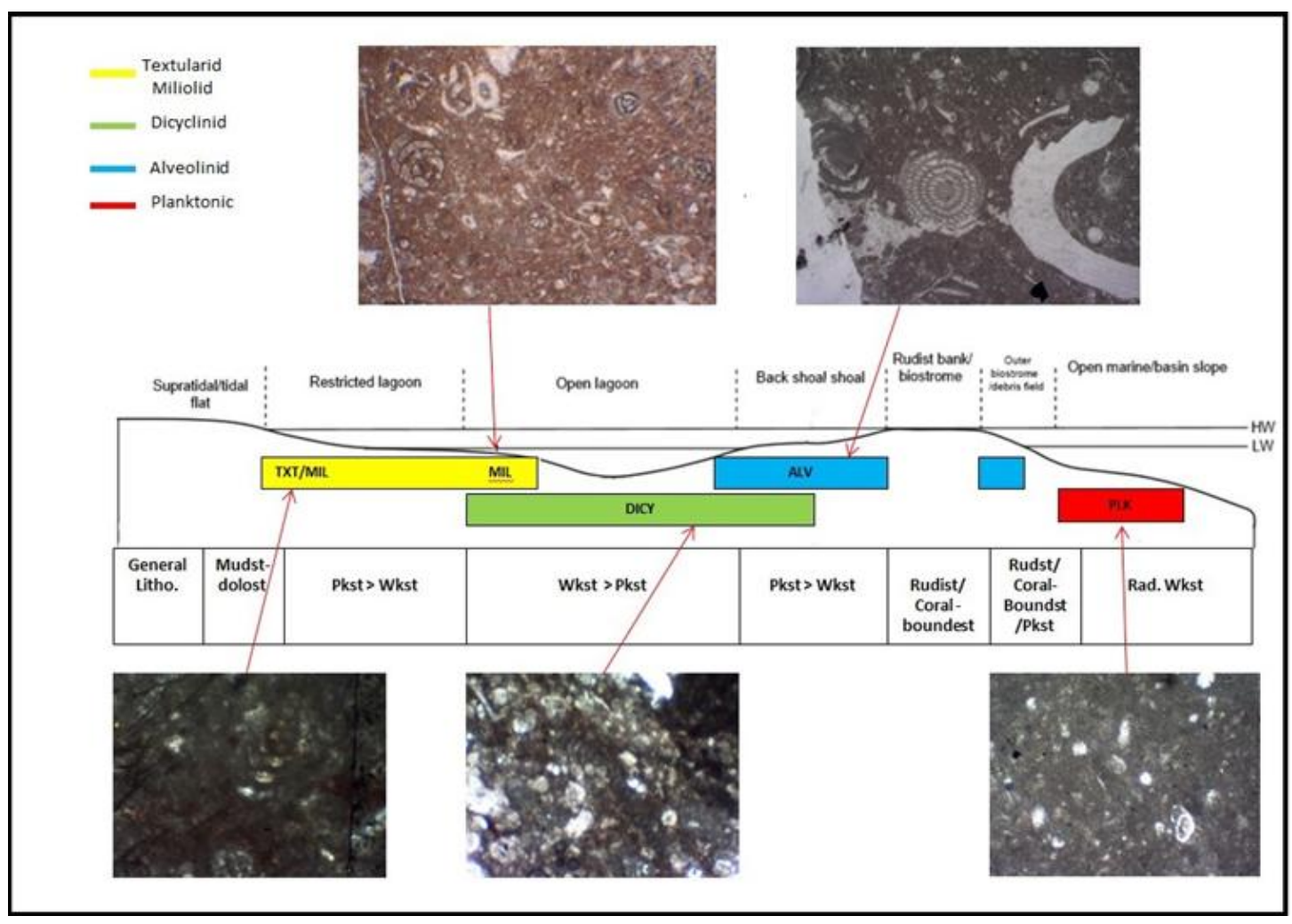

Fig9. Suggested sedimentary model of microfacies to the Mishrif Formation, at North Rumaila oilfield

\section{CONCLUSION}

The Mishrif Formation in the North Rumaila oilfield as represents as a carbonate platform ramp system, with scattered patch reefs and shoals developed across the ramp margin and the platform top.

- Echinoderm and benthic foraminifera-dominated shoal facies appear to have prefer to develop on platform top settings, whilst the rudist and echinoderm-dominated shoal facies present across a more spread area, both in front and behind the rudist patch reefs, mainly within the platform margin.

- A thick sedimentation of grainy shoal facies was consist deposited around the R-027/R-033 area on the platform top, while surrounding areas were characterized by lagoonal sedimentation.

- In $\mathrm{mB}$, reservoir quality appears to be best developed in the grainy shoal and patch reef facies mainly found in the platform margin in the lower part of $\mathrm{mB}$, but also happening as limited bodies in the wide lagoonal setting in the upper part of $\mathrm{mB}$. Diagenetic control on reservoir quality is controlled by depositional fabrics and composition. Open lagoon facies commonly moderate reservoir quality within a mixed micropore/macropore-dominated pore system and can supply a degree of connectivity between the mixed grain-rich bodies. Mid-ramp facies also moderate reservoir quality within micrte-dominated pore system, while peritidal lagoon and outer ramp facies characterized by poor quality reservoir with high cemented and non- microporous which is represent good barrier between upper part and lower part of $\mathrm{mB}$, which can prevent vertical fluid flow between the better quality, grain-rich facies of lower and upper part of $\mathrm{mB}$ unit

- In mA unit, the best reservoir quality is occurred in the grainier facies associated with biostromes and grain sheets. However, these facies can be locally affected by strong cementation, causing decreasing in reservoir quality (low porosity and low permeability). In the micritic facies of the inner ramp and open lagoon facies associations the quality reservoir for $\mathrm{mA}$ unit is moderate. Intertidal to supratidal facies which are found in the upper part of mA unit in well R-012, R-013 and R-436 are associated with poor reservoir quality due to the strong diagenesis especially cementation process modification affecting most beds. 


\section{REFERENCES}

[1] Al-Ameri, T. K., Pitman, J., Naser, M. E., Zumberge, J., \& Al-Haydari, H. A. (2011). Programed oil generation of the Zubair Formation, Southern Iraq oil fields: results from Petromod software modeling and geochemical analysis. Arabian Journal of Geosciences, Vol.4(7-8), pp.1239-1259.

[2] Al-Dabbas, M., Al-Jassim, J., \& Al-Jumaily, S. (2010), Depositional environments and porosity distribution in regressive limestone reservoirs of the Mishrif Formation, Southern Iraq, Arabian Journal of Geosciences, vol.3(1), pp. 67-78.

[3] Aqrawi AAM (1995) Brackish-water and evaporitic $\mathrm{Ca}-\mathrm{Mg}$ carbonates in the Holocene Lacustrine/deltaic deposits of southern Mesopotamia. J Geol Soc Lond 152:259-268.

[4] Aqrawi, A. A., Goff, J. C., Horbury, A. D., \& Sadooni, F. N. (2010). The petroleum geology of Iraq. Scientific Press.

[5] Chatton M, Hart E (1961) Review of the Cenomanian to Maastrichtian stratigraphy in Iraq. Manuscript report No. 2/141, INOC Library, Baghdad.

[6] Dunham RJ (1962) Classification of carbonate rocks according to depositional texture. In: Ham WE (ed) Classification of carbonate rocks: American Association of Petroleum Geologists Memoir, pp 108-121.

[7] Embry, A. F., \& Klovan, J. E. (1972). Absolute water depth limits of Late Devonian paleoecological zones. Geologische Rundschau, vol.61(2), pp 672-686.

[8] Flugel, E. (2010). Microfacies of carbonate rocks: analysis, interpretation and application. Springer Science \& Business Media, Perlin, 984p.

[9] Folk RL (1962) Spectral subdivision of limestone types. In: Ham WE (ed) Classification of Carbonate Rocks-A Symposium:American Association of Petroleum Geologists Memoir 1, pp 62-84.

[10] Karim, H. H. (1992). Structural nature of lower Mesopotamian region from geophysical observations. In Proceeding of 3rd symposium on Oceanography of Khour Al-Zubair, Marine Science Center Basrah, pp. $15-25$.

[11] Wright, V. P. (1992). A revised classification of limestones. Sedimentary Geology, vol.76 (3-4), pp 177185.

Citation: Muslim M. Al-Ali, et.al, (2019)" Microfacies and Depositional Environment of Mishrif Formation, North Rumaila Oilfield, Southren Iraq", Southeast Cameroon, International Journal of Mining Science (IJMS), 5(3), pp.1-10, DOI: http://dx.doi.org/10.20431/2454-9460.0503001

Copyright: () 2019 Authors. This is an open-access article distributed under the terms of the Creative Commons Attribution License, which permits unrestricted use, distribution, and reproduction in any medium, provided the original author and source are credited 